\title{
Yield, Nitrogen Dynamics, and Fertilizer Use Efficiency in Machine-harvested Cucumber
}

\author{
Laura L. Van Eerd ${ }^{\mathbf{1}}$ and Kelsey A. O'Reilly \\ Department of Land Resource Science, University of Guelph, Ridgetown \\ Campus, Ridgetown, Ontario, NOP 2CO, Canada
}

Additional index words. Cucumis sativus, nitrate, soil mineral nitrogen, harvest index, pickles, brine quality

\begin{abstract}
The increase in fertilizer costs as well as environmental concerns has stimulated growers to re-evaluate their fertilizer applications to optimize nitrogen use efficiency (NUE) while maintaining crop yields and minimizing $N$ losses. With these objectives, field trials were conducted at seven sites with five $N$ rates ( 0 to $220 \mathrm{~kg} N / \mathrm{ha}$ ) of ammoniumnitrate applied preplant broadcast and incorporated as well as a split application treatment of $65+45 \mathrm{~kg} \mathrm{~N} / \mathrm{ha}$. In three contrasting years (i.e., cool/wet versus warm/dry versus average), $N$ treatment had no observable effect on grade size distribution or brine quality. Based on the zero $\mathbf{N}$ control treatment, the limited yield response to fertilizer $\mathbf{N}$ was the result of sufficient plant-available $\mathrm{N}$ over the growing season. In the $\mathrm{N}$ budget, there was no difference between $\mathrm{N}$ treatments in crop $\mathrm{N}$ removal, but there was a positive linear relationship between $\mathrm{N}$ applied and the quantity of $\mathrm{N}$ in crop residue as well as in the soil after harvest. As expected, apparent fertilizer $\mathrm{N}$ recovery and $\mathrm{N}$ uptake efficiency were lower at 220 versus $110 \mathrm{~kg} \mathrm{~N} / \mathrm{ha}$ applied preplant or split. The preplant and split applications of $110 \mathrm{~kg}$ N/ha were not different in yield, overall $\mathrm{N}$ budget, or NUE. Considering the short growing season, planting into warm soils, and the generally productive, nonresponsive soils in the region, growers should consider reducing or eliminating fertilizer $\mathbf{N}$ applications in machine-harvested cucumber.
\end{abstract}

Nitrogen is a critical nutrient for crop production, but it is difficult to optimize nitrogen $(\mathrm{N})$ fertilizer applications because of the dynamic nature of plant-available $\mathrm{N}$ over the growing season. Nitrogen availability affects yield and quality of vegetables. Nitrogen applications should be carefully managed, particularly in cucumbers ( $\mathrm{Cucu}$ mis sativus L.), to optimize marketable yield while minimizing excessive vine growth, which can impede harvest operations and reduce marketable yield.

Optimal $\mathrm{N}$ rates of field-grown cucurbits vary depending on cucurbit species and location and range from 80 to $200 \mathrm{~kg} \mathrm{~N} / \mathrm{ha}$ (Esmel et al., 2006; Ferrante et al., 2008; Mohammad, 2004). In Ontario, there is no difference among cucurbit crops in the recommended rate of $\mathrm{N}$ fertilizer, which is $110 \mathrm{~kg} \mathrm{~N} / \mathrm{ha}$, split applied at $65+45 \mathrm{~kg} \mathrm{~N} / \mathrm{ha}$ preplant and before the vines elongate, respectively. Although not well documented,

Received for publication 6 Feb. 2009. Accepted for publication 17 July 2009.

We acknowledge the contributions of Mike Zink, Rob Grohs, Anne Verhallen, Elaine Roddy, and Ivan O'Halloran and the financial and in-kind contributions of Ontario Processing Vegetable Growers (OPVG) and Ontario Food Processors Association (OPFA), Ontario Ministry of Agriculture, Food and Rural Affairs (OMAFRA), AgriFood Laboratories Ltd., and A\&L Laboratories Inc. We are especially grateful to grower cooperators. ${ }^{1}$ To whom reprint requests should be addressed; e-mail lvaneerd@ridgetownc.uoguelph.ca. this recommendation is believed to have been developed by the Ontario Ministry of Agriculture, Food, and Rural Affairs at least 30 years ago on hand-picked cucumber production systems. It is unclear whether this rate is appropriate for machine-harvested cucumbers because machine-harvested cucumbers are grown at a higher plant population $(\approx 131,000$ versus $60,600 \mathrm{ha})$, have a shorter growing season ( 6 versus $\approx 12$ weeks), and lower yields $\left(\approx 9\right.$ versus 18 to $27 \mathrm{t} \cdot \mathrm{ha}^{-1}$ ) than hand-picked cucumbers. Consequently, there is a need to evaluate recommended $\mathrm{N}$ rates on machine-harvested cucumbers.

Cucumbers are a valuable crop in Ontario, grossing over $\$ 9.1$ million of farm value from 1110 ha harvested in 2007 (Mailvaganam, 2008). Appearance (size, shape, and color) of fresh and processed vegetables influences consumer-purchasing decisions. Nitrogen nutrition can affect vegetable external and postharvest quality (Locascio et al., 1984). However, little is known about the effect of $\mathrm{N}$ fertility on brine quality of cucumbers, although nearly all processing cucumbers in North America are brined. Nitrogen management recommendations must be based not only on yields and economics, but also on cucumber quality as well as environmental considerations.

Generally, previous production research relied heavily on agronomic and economic objectives with little regard for the environment or nutrient use efficiency (Beegle et al., 2000). The intensification of agricultural production and increased pressure from society on growers to protect consumers and the environment has increased the need for optimizing $\mathrm{N}$ use efficiency (NUE). This is particularly true in cucurbit crops, in which plant $\mathrm{N}$ uptake and soil $\mathrm{N}$ dynamics have been quantified in squash (Mohammad, 2004), but differences in crop species, climate, soil characteristics, and crop management may significantly influence results. Understanding $\mathrm{N}$ dynamics and optimizing fertilizer NUE in machine-harvested cucumber under typical production practices may lead to best management practice recommendations that balance agronomic, economic, and environmental considerations. The objectives of this study were to characterize the response of machine-harvested cucumber to fertilizer $\mathrm{N}$ rates and time of application with respect to 1) the yield, quality, and brine quality to estimate the most economical rate of $\mathrm{N} ; 2$ ) total $\mathrm{N}$ budget to estimate N losses; and 3) NUE to reduce input costs.

\section{Materials and Methods}

Experimental design. From 2004 to 2006, field experiments on machine-harvested cucumbers, cv. Vlaspic, were conducted in different fields at the University of Guelph Ridgetown Campus and at grower sites in southwestern Ontario for 7 site-years (Table 1). Cucumber seed was planted at 131,000 plants/ha with $76 \mathrm{~cm}$ between plant rows and $10 \mathrm{~cm}$ between plants. The experiments had randomized complete block designs with four replications at two to three sites each year. Sites were representative of the processing cucumber industry with respect to soil texture and previous crop (Table 1). Ammonium nitrate was preplant-applied at $0,65,110,220$, and $\mathrm{x} \mathrm{kg} \mathrm{N} / \mathrm{h}$, in which $\mathrm{x}$ was $165 \mathrm{~kg} \mathrm{~N} / \mathrm{ha}$ in 2004 and $30 \mathrm{~kg} \mathrm{~N} / \mathrm{ha}$ in 2005 and 2006. This change was made to reflect expected yield response. At all sites in 2004 and at the cooperator sites in 2005 and 2006, plots were at least $3.35 \mathrm{~m}$ or seven rows wide and $8 \mathrm{~m}$ long with $\mathrm{N}$ fertilizer hand broadcast immediately after planting. At all other sites, plots were $6 \mathrm{~m} \times 8 \mathrm{~m}$ and $\mathrm{N}$ fertilizer was hand-applied and incorporated before planting (Table 2). A split $\mathrm{N}$ application of $65+$ $45 \mathrm{~kg} \mathrm{~N} / \mathrm{ha}$ was applied preplant as described and by hand before the vine elongation, respectively. Fertilization was based on soil testing for all nutrients other than $\mathrm{N}$ and typical Ontario production practices were followed for pest control and other field operations. Air and soil temperature and precipitation data were collected at all sites.

Soil mineral $\mathrm{N}$ and plant total $\mathrm{N}$ were determined for only 0,110 , and $220 \mathrm{~kg} \mathrm{~N} / \mathrm{ha}$ treatments as well as the split treatment in 2005 and 2006. These $\mathrm{N}$ treatments were selected for evaluation because they encompass the range of $\mathrm{N}$ fertilization rates tested and the Ontario-recommended $\mathrm{N}$ rate for cucumbers is $65+45 \mathrm{~kg} \mathrm{~N} / \mathrm{ha}$. It was assumed that NUE and N dynamic parameters between the 0 and $220 \mathrm{~kg} \mathrm{~N} /$ ha treatments would be intermediary. 


\begin{tabular}{|c|c|c|c|c|c|c|c|c|c|c|c|c|}
\hline \multirow[b]{2}{*}{ Site } & \multirow[b]{2}{*}{ Year } & \multirow{2}{*}{$\begin{array}{l}\text { Previous } \\
\text { crop }\end{array}$} & \multirow{2}{*}{ 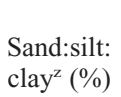 } & \multirow{2}{*}{$\begin{array}{c}\text { Organic } \\
\text { matter }(\%)\end{array}$} & \multirow[b]{2}{*}{$\mathrm{pH}$} & \multirow{2}{*}{$\begin{array}{c}\text { Cation } \\
\text { exchange capacity } \\
(\mathrm{MEQ} / 100 \mathrm{~g})\end{array}$} & \multicolumn{6}{|c|}{ Preplant nutrients $\left(\mathrm{mg} \cdot \mathrm{kg}^{-1}\right)$} \\
\hline & & & & & & & $\mathrm{NO}_{3}{ }^{-}-\mathrm{N}$ & $\mathrm{NH}_{4}{ }^{+}-\mathrm{N}$ & Phosphorus & Potassium & Calcium & Magnesium \\
\hline Harwich & 2004 & Seed corn & $24: 60: 16$ & 4.0 & 7.2 & 24.7 & 15.6 & 2.4 & 56.4 & 220 & 4,029 & 330 \\
\hline Ridgetown Campus ${ }^{\mathrm{y}}$ & 2004 & Soybeans & $74: 16: 10$ & 3.0 & 5.4 & 9.3 & 27.9 & 5.4 & 60.7 & 218 & 783 & 81.3 \\
\hline Harwich & 2005 & Seed corn & $32: 52: 16$ & 4.0 & 7.2 & 24.7 & 24.0 & 0.9 & 56.0 & 220 & 4,029 & 330 \\
\hline Ridgetown Campus & 2005 & Soybeans & $51: 33: 16$ & 4.8 & 7.3 & 23.0 & 20.6 & 3.1 & 22.0 & 109 & 3,928 & 167 \\
\hline Fairview & 2005 & Soybeans & $45: 47: 08$ & 2.2 & 7.8 & 23.0 & 14.9 & 2.1 & 24.0 & 115 & 3,972 & 160 \\
\hline Ridgetown Campus & 2006 & Soybeans & $72: 21: 07$ & 3.3 & 6.0 & 12.0 & 5.3 & 2.2 & 30.0 & 133 & 910 & 42.0 \\
\hline Fairview & 2006 & Soybeans & $24: 55: 21$ & 3.0 & 7.6 & 24.9 & 31.1 & 2.3 & 18.0 & 115 & 4,104 & 341 \\
\hline
\end{tabular}

${ }^{\text {z}}$ Soil sample depth $15 \mathrm{~cm}$ for all parameters except $\mathrm{NO}_{3}{ }^{-}-\mathrm{N}$ and $\mathrm{NH}_{4}{ }^{+}-\mathrm{N}$, which was $30 \mathrm{~cm}$.

${ }^{\mathrm{y}}$ Different fields were used each year at site.

Table 2. Dates of crop management practices performed at experimental sites.

\begin{tabular}{lcccc}
\hline & & & Date \\
\cline { 3 - 4 } Site & Year & $\begin{array}{c}\text { Cucumber planting } \\
\text { and preplant } \\
\text { N application }\end{array}$ & $\begin{array}{c}\text { Split N } \\
\text { application }\end{array}$ & $\begin{array}{c}\text { Cucumber } \\
\text { harvest }\end{array}$ \\
\hline Harwich & 21 June & 20 July & 6 Aug. \\
Ridgetown Campus & 2004 & 27 May & 9 July & 27 July \\
Harwich & 2005 & 17 June & 5 July & 28 July \\
Ridgetown Campus & 2005 & 26 May & 28 June & 15 July \\
Fairview & 2005 & 31 May & 23 June & 20 July \\
Ridgetown Campus & 2006 & 29 May & 3 July & 18 July \\
Fairview & 2006 & 6 June & 3 July & 24 July \\
\hline
\end{tabular}

Soil mineral nitrogen measurements. Inorganic $\mathrm{N}$ concentration $\left(\mathrm{NO}_{3}{ }^{-} \mathrm{N}\right.$ and $\left.\mathrm{NH}_{4}{ }^{+}-\mathrm{N}\right)$ was determined on one composite soil sample taken from at least five cores (typically six to 10 cores) to $75-$ or $90-\mathrm{cm}$ depths from each block before planting and from each plot of selected treatments at the time of split $\mathrm{N}$ application and at harvest (Table 2). In the field, soil cores were divided into 15 - or 30$\mathrm{cm}$ increments, homogenized by depth, sealed in plastic bags, and put into a cooler for transport. Samples were frozen $\left(-20^{\circ} \mathrm{C}\right)$, stored, and sent for analysis to an Ontariocertified laboratory (Agri-Food Laboratories Ltd., Guelph, Ontario, Canada).

Soil $\mathrm{NO}_{3}{ }^{-}-\mathrm{N}$ and $\mathrm{NH}_{4}{ }^{+}-\mathrm{N}$ were quantified using the Maynard et al. (2008) method, which consisted of $\mathrm{KCl}$ extraction with cadmium reduction and the phenate method, respectively, using an Auto Analyzer (Technicon Auto Analyzer II; Tarrytown, New York, NY). Preplant soil characteristics and bulk density were evaluated according to accredited standards (Gregorich and Carter, 2008) on composite 15 -cm depth soil cores sampled from the entire trial area. They included $\mathrm{pH}(1: 1 \mathrm{v} / \mathrm{v}$ method), organic matter (modified Walkley Black method), phosphorus (Olson bicarbonate extraction method), calcium, potassium, magnesium, sodium (atomic absorption through ammonium acetate extraction), zinc, iron, copper (DTPA extraction for atomic adsorption), manganese (phosphoric acid extraction with atomic adsorption), percentage sand/silt/clay (hydrometer method), and cation exchange capacity (estimated based ammonium acetate extraction and $\mathrm{pH}$ ).

Crop measurements. Six meters of the center three to five rows, depending on plot width, were hand-harvested to simulate onceover machine harvest. The entire trial was harvested when it was estimated that $\approx 10 \%$ of the fruit were Grade 4 (Schultheis et al., 1998). Based on market standards in Ontario, fruit was graded according to size (Table 3); cucumbers not suitable for pickling as a result of shape or size were considered culls and were included in total yield calculations. Harvest area, fresh fruit weight, and grade were used to calculate total and marketable yield and income on a per-hectare basis to allow for comparisons among treatments.

For one site each year, a representative sample of Grade 3 cucumbers was analyzed for brine quality. Mesh bags containing 12 to 15 cucumbers from each plot were placed in a 200-L plastic drum and brine solution was added. During the 14-d fermentation, the barrel was continuously aerated. The barrel was stored outside until quality assessments were made in December. Ten representative pickles were dissected longitudinally to quantify percent recovery and to assess quality parameters on a 1 to 5 rating scale in which a rating of 3 was considered the industry standard. Pickle shape, ridges and spines, external and internal color, firmness, placenta size, seed size, and overall quality parameters were assessed according to the pickling industry standards in Ontario ( $\mathrm{J}$. O'Sullivan, personal communication).

Aboveground vegetative biomass (i.e., leaves and vines) collected from five plants per plot at harvest and a representative sliced sample of $10 \%$ of each cucumber grade were dried at $60{ }^{\circ} \mathrm{C}$ for total $\mathrm{N}$ analysis. A representative sample of dried plant tissue was ground in a Wiley mill with a $2-\mathrm{mm}$ diameter opening mesh screen. Total $\mathrm{N}$ content in plant biomass was determined by dry combustion method (McGill and Figueiredo, 2008) using a LECO CN determinator (Leco Corporation, St. Joseph, MI) at an Ontariocertified laboratory (A\&L Laboratories Inc., London, Ontario, Canada). Percent total N
Table 3. Grade sizes and price paid by the processor in 2005 to 2006 for machine-harvested cucumbers.

\begin{tabular}{lcc}
\hline Grade no. & Diam $(\mathrm{cm})$ & Price $(\mathrm{US} \$ / \mathrm{t})$ \\
\hline 1 & Up to 2.7 & $\$ 623$ \\
2 & 2.7 to 3.8 & $\$ 223$ \\
3 & 3.8 to 5 & $\$ 154$ \\
4 & 5 to 5.4 & $\$ 45^{\mathrm{z}}$ \\
Oversize & $>5.4$ & $\$ 45^{\mathrm{z}}$ \\
Culls, nubs, & Damaged or & \\
$\quad$ and crooks & misshapen & $\$ 0$ \\
\hline
\end{tabular}

${ }^{\mathrm{z}}$ If accepted by the processor.

content data were converted to $\mathrm{kg} \mathrm{N} /$ ha based on yield and shoot dry weights.

Nitrogen use efficiency and budget calculations. Nitrogen use efficiency indices and $\mathrm{N}$ budgets were calculated using plant dry matter weights in aboveground plant $(P w$ $=V w+Y w)$, vegetative $(V w$, leaves and vines), and fruit yield $(Y w)$ in $\mathrm{kg} \cdot \mathrm{ha}^{-1}$. Nitrogen content in the plant $(P n)$, vegetative $(V n)$, and fruit yield $(Y n)$, in $\mathrm{kg} \mathrm{N} / \mathrm{ha}$, was determined by multiplying percent total $\mathrm{N}$ content by dry matter content. Soil mineral $\mathrm{N}$ content (Sn) as $\mathrm{NO}_{3}{ }^{-}-\mathrm{N}$ and $\mathrm{NH}_{4}{ }^{+}-\mathrm{N}$ content were calculated to $30-\mathrm{cm}$ depth and the data were converted to $\mathrm{kg} \mathrm{N} / \mathrm{ha}$ based on soil bulk density. Fertilizer uptake efficiency was calculated as the difference in total aboveground plant $\mathrm{N}$ content in a fertilized treatment from zero $\mathrm{N}$ control treatment divided by $\mathrm{N}$ fertilizer. Nitrogen uptake efficiency was aboveground plant $\mathrm{N}$ divided by mineral $\mathrm{N}$ in the soil at harvest. Standardized N removal was the amount of $\mathrm{N}$ removed from the field in cucumber yield divided by yield weight. All NUE indices were multiplied by 100 .

Statistical analysis. Yield, income, percent $\mathrm{N}$ content, vegetative biomass, and soil $\mathrm{N}$ content data were subjected to linear and quadratic regression (SAS Version 8.2; SAS Inc., Cary, NC). For all other data, 2004 data were analyzed separately from 2005 and 2006 because 1) the split application was not sampled; 2) there were only two, not three, sites; and 3) soil was sampled at different depths. Data were subjected to analysis of variance using type I sums of squares in PROC MIXED model (SAS Version 8.2; SAS Inc.) with site and replication as random effects and $\mathrm{N}$ application and year as fixed effects. Means separation was determined using Tukey-Kramer multiple comparison procedure. The Type I error $(\alpha)$ was set at 0.1 . 


\section{Results and Discussion}

Cucumber crop response to nitrogen. Nitrogen treatment had no observable effect on seedling emergence and growth during the season, although nonfertilized control plants were chlorotic in 2005. At harvest, year and $\mathrm{N}$ treatment had no effect on cucumber size grade distribution, but there was a significant year $\times$ grade interaction. Cucumbers were targeted for harvest when $10 \%$ of the yield was Grade 4 and this was realized in 2004 and 2006 at $15 \%$ and $8 \%$, respectively. The 2005 harvest was later than ideal at 23\% Grade 4 attributable mainly to drought conditions limiting yield and delaying the decision to harvest. Nitrogen treatment had no effect on the size grade distribution, including culls (data not shown). Similarly, in central Alabama, 56 or $112 \mathrm{~kg} \mathrm{~N} / \mathrm{ha}$ did not influence size grade distribution in hand-picked cucumbers grown in either spring or fall (Doss et al., 1977).

Cucumber yield and income. Income (Fig. 1) or marketable cucumber yield (data not shown) response to $\mathrm{N}$ application was either nonresponsive or tended to be a slight positive or negative linear response. It was not possible to determine the most economical rate of $\mathrm{N}$ for machine-harvested cucumber. There was no $\mathrm{N}$ treatment effect on cucumber yield expressed as income in dollars/ha or cucumber yields in $\mathrm{t} \cdot \mathrm{ha}^{-1}$, indicating no income difference between the preplant versus split of $110 \mathrm{~kg} \mathrm{~N} /$ ha (Fig. 1). Overall, income ranged from $\approx \$ 1600$ to $\$ 6500 /$ ha for all site-years. These yields are comparable to the 2004 to 2006 provincial average for fresh and processing cucumbers and gherkins of $\approx \$ 5000 /$ ha. Income was highest in 2004 (Fig. 1), a relatively cool and wet season (Table 4). Although there were drought conditions in 2005 (Table 4), income and yield were only slightly lower than in 2006, an average year for temperature and precipitation, because a new disease in Ontario, downy mildew [Pseudoperonospora cubensis (Berk. \& Curt.) Rostov.], reduced yields. There were considerable production losses as a result of downy mildew, where $42 \%$ of Ontario processing cucumber growers met less than $50 \%$ of their contracted tonnage (E. Roddy, personal communication).

Some studies have shown a positive or no response of cucumber yield to increasing $\mathrm{N}$ rates (Doss et al., 1977; Umamaheswarappa and Krishnappa, 2004). Other cucurbits such as watermelon [Citrullus lanatus (Thunb.) Matsum \& Nakai] (Goreta et al., 2005), summer squash (Cucurbita pepo L.) (Esmel et al., 2006), and pumpkins (Cucurbita pepo L.) (Reiners and Riggs, 1997) have variable or no yield response to $\mathrm{N}$ fertilization. Johnson et al. (1973) found cucumber yield response to $\mathrm{N}$ rate to be variable depending on soil type, where the greatest response was on eroded, upland soils and no response on highly productive soils. The sites in our experiment were selected to represent soils and rotations typical of cucumber production in southwestern Ontario, which are typically

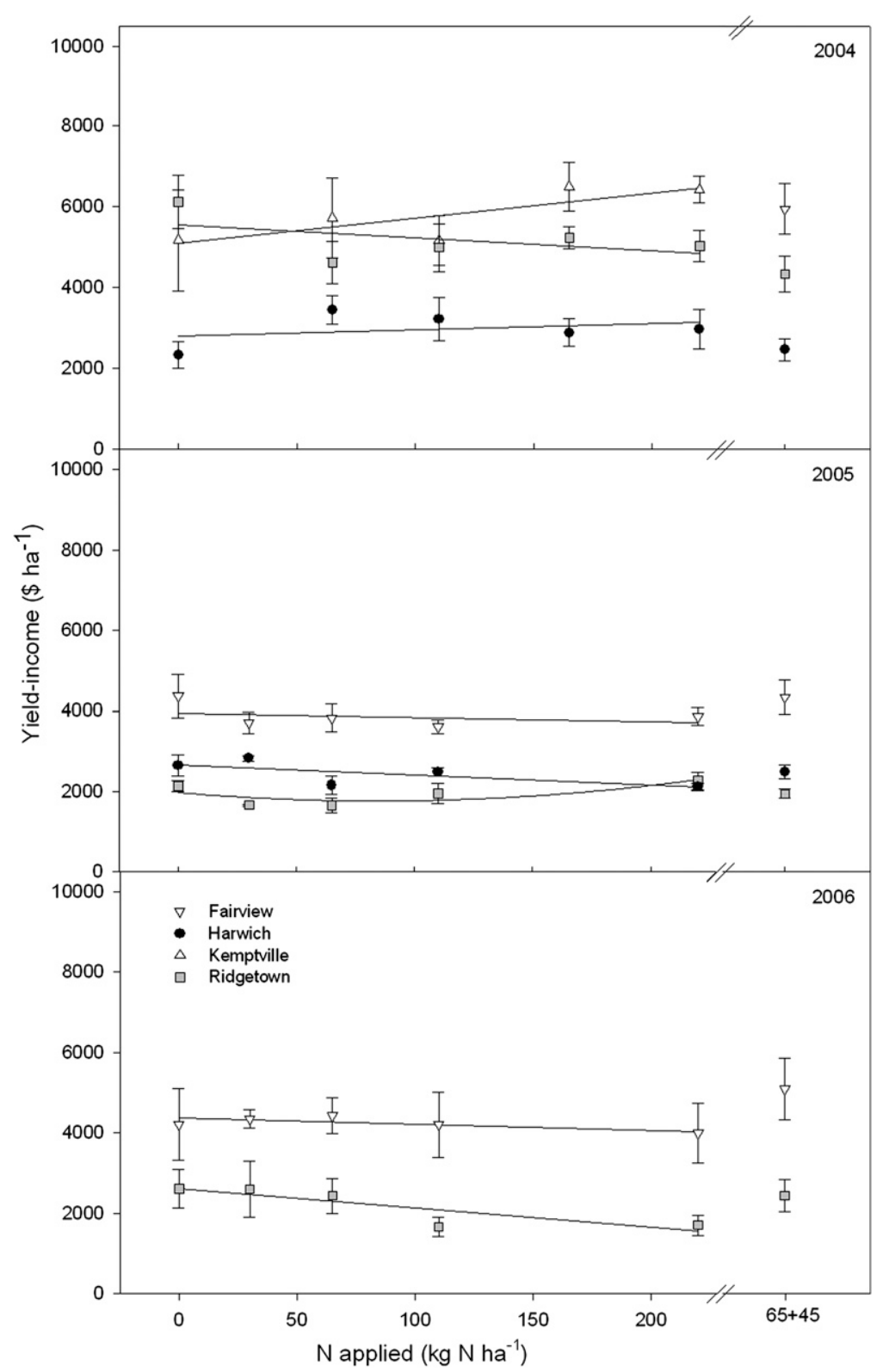

Fig. 1. Machine-harvested cucumber income [expressed as dollars/ha based on grade size and price (Table $3)$ ] response to ammonium nitrate broadcast-applied preplant incorporated or split-applied when the vines elongate $(65+45)$

fertile. Nitrogen analysis confirmed that the sites had considerable soil mineral $\mathrm{N}$ at preplant, in-season, and harvest sampling. Thus, in southwestern Ontario, there was minimal cucumber yield increase per unit $\mathrm{N}$ applied compared with nonfertilized control. Considering fertilizer and application costs and yield return, a grower should consider lowering $\mathrm{N}$ rates and avoiding split $\mathrm{N}$ application of $110 \mathrm{~kg} \mathrm{~N} / \mathrm{ha}$.

Cucumber brine quality. Brine quality was unaffected by fertilizer $\mathrm{N}$ treatment or site-year and there were no $\mathrm{N}$ treatment $x$ year interactions. All brine quality parameters (i.e., percent recovery, shape, ridges and spines, external and internal color, firmness, placenta size, seed size, and overall quality) were within the industry standard (data not shown). The lack of influence of $\mathrm{N}$ on fruit quality parameters such as fruit size and
Table 4. Monthly mean temperature and total rainfall at the University of Guelph Ridgetown Campus, Ridgetown, Ontario, Canada, in 2004 to 2006 as compared with the 30 -year mean.

\begin{tabular}{lrrrc}
\hline Month & 2004 & 2005 & 2006 & 30-year mean \\
\hline \multicolumn{5}{c}{ Temperature $\left.{ }^{\circ} \mathrm{C}\right)$} \\
May & 14.5 & 11.7 & 14.2 & 13.6 \\
June & 18.3 & 22.1 & 18.2 & 18.8 \\
July & 20.4 & 22.4 & 21.8 & 21.5 \\
Mean & 17.7 & 18.7 & 18.1 & 18.0 \\
& \multicolumn{5}{c}{ Rainfall $(\mathrm{mm})$} \\
May & 137.8 & 36.0 & 83.8 & 80.9 \\
June & 98.0 & 28.8 & 55.0 & 79.5 \\
July & 128.4 & 64.0 & 98.2 & 87.8 \\
Total & 364.2 & 128.8 & 237.0 & 248.2 \\
\hline
\end{tabular}

overall fruit quality was similar to results on watermelon (Schultheis and Dufault, 1994) and were likely the result of sufficient levels of plant-available N. The sufficiency 
range of $\mathrm{N}$ for most vegetables is large, and when vegetables are grown within this range, the effects of $\mathrm{N}$ on external fruit quality parameters are small (Locascio et al., 1984). In contrast, increased rates of $\mathrm{N}$ application increased flesh and placenta thickness of cucumber cv. Poinsette fruit (Umamaheswarappa and Krishnappa, 2004). No literature was found on the impact of fertility on field cucumber brine quality.

Soil mineral nitrogen. There was no difference in interpretation of soil mineral $\mathrm{N}$ data expressed in $\mathrm{kg} \mathrm{N} / \mathrm{ha}$ (data not shown) or $\mathrm{mg} \cdot \mathrm{kg}^{-1}$. Averaged over sites, preplant soil mineral $\mathrm{N}$ at the end of May to mid-June was significantly higher in 2004 than 2005 and 2006 at 17.6 and $10.3 \mathrm{mg} \cdot \mathrm{kg}^{-1}$, respectively, which is not atypical for the time of year in warm, productive soils. In all 3 years, soil $\mathrm{NO}_{3}{ }^{-}-\mathrm{N}$ was lower at the deeper depths (i.e., 60 to 75 or 60 to $90 \mathrm{~cm}$ ) than the top depth (i.e., 0 to 15 and 0 to $30 \mathrm{~cm}$ ) at preplant and harvest sampling (data not shown). In the zero $\mathrm{N}$ control, there was no difference between preplant and harvest in soil mineral $\mathrm{N}$ in the 2004. Soil mineral N in 2005 and 2006 was higher preplant than harvest from 0 to $30 \mathrm{~cm}$. Considering that trials were in different fields with either soybeans [Glycine $\max$ (L.) Merr.] or seed corn (Zea mays L.) as the previous crop (Table 1), it is difficult to determine if this effect was the result of a site or year effect.

At harvest, there was a significant positive linear relationship between $\mathrm{N}$ fertilizer and soil $\mathrm{NO}_{3}^{-}-\mathrm{N}, \mathrm{NH}_{4}^{+}-\mathrm{N}$ (Fig. 2) and soil mineral $\mathrm{N}$ concentrations (data not shown). Similar trends of higher $\mathrm{NO}_{3}{ }^{-}-\mathrm{N}$ levels at harvest with fertilizer $\mathrm{N}$ applications than control treatments have been observed by others (Fang et al., 2006; Gagnon et al., 1998; Habtegebrial et al., 2007; Mohammad, 2004). There was no difference in $\mathrm{NO}_{3}{ }^{-}-\mathrm{N}, \mathrm{NH}_{4}{ }^{+} \mathrm{N}$ and soil mineral $\mathrm{N}$ quantified at harvest between preplant and split $\mathrm{N}$ fertilizer applications of $110 \mathrm{~kg} \mathrm{~N} / \mathrm{ha}$ (Fig. 2). Thus, split-applying $\mathrm{N}$ did not minimize the quantity of mineral $\mathrm{N}$ available for loss after harvest.

Nitrogen budget. Trends between $\mathrm{N}$ treatments in 2004 (data not shown) were not different from 2005 and 2006. For 2005 and 2006 , there were no significant $\mathrm{N}$ treatment $\times$ year interactions for all $\mathrm{N}$ budget parameters tested (Table 5); therefore, data were pooled. Year had a significant effect on all $\mathrm{N}$ budget parameters except crop removal balance $(F$ $\mathrm{Yn}$ ) and apparent $\mathrm{N}$ loss (Nin-Nout). Where year was significant, $\mathrm{N}$ budget parameters were greater in 2005 than 2006. Likely, the dry, hot growing conditions resulted in higher plant $\mathrm{N}$ uptake, lower immobilization, more mineralization, and/or less $\mathrm{N}$ losses through leaching or denitrification.

The timing of $\mathrm{N}$ fertilizer did not influence $\mathrm{N}$ budget parameters. Nitrogen treatment had a significant effect on all $\mathrm{N}$ budget parameters except crop $\mathrm{N}$ removal $(Y n)$ and crop residue $\mathrm{N}(V n)$ (Table 5). Thus, regardless of the quantity or timing of $\mathrm{N}$ fertilizer, $\mathrm{N}$ content in the cucumber plant, expressed as $\mathrm{kg} \cdot \mathrm{ha}^{-1}$, was not different. Moreover, the
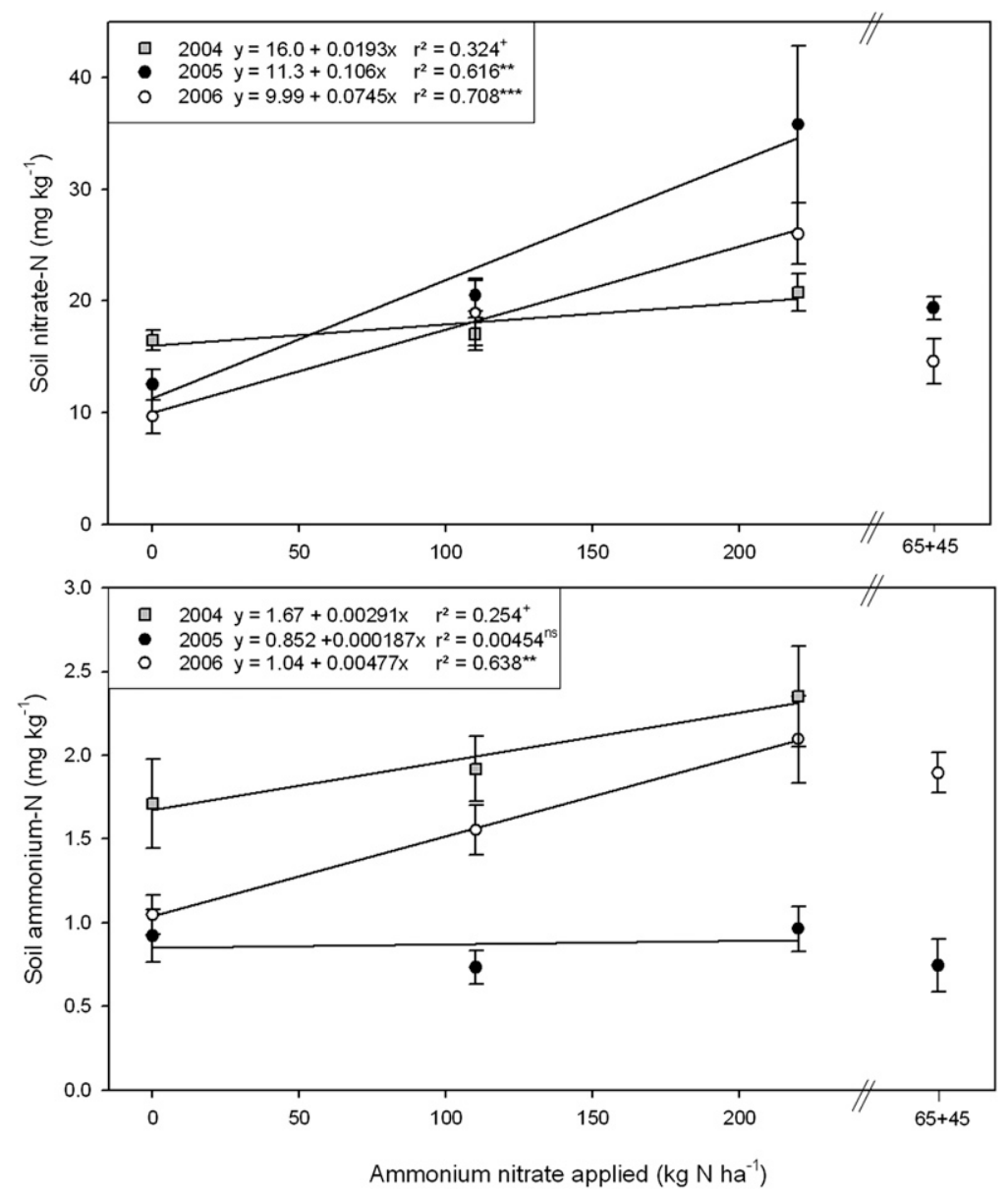

Fig. 2. Soil nitrate-N and ammonium-N (lower) concentrations $\left(\mathrm{mg} \cdot \mathrm{kg}^{-1}\right)$ in soil at harvest of machineharvested cucumber response to ammonium nitrate broadcast-applied preplant incorporated or splitapplied when the vines elongate $(65+45)$. Date averaged across site for each year. Correlation coefficients were significant at $P \leq 0.1^{+}, 0.05^{*}, 0.01^{* *}$, and $0.001^{* * *}(\mathrm{n} \geq 8)$.

partitioning of $\mathrm{N}$ and biomass between vegetative and reproductive tissues (i.e., harvest index) was not influenced by quantity or timing on $\mathrm{N}$ applied, which was consistent with other crops (Olsen et al., 1993; Van Eerd, 2007). Approximately $22 \%$ and $26 \%$ of total aboveground plant $\mathrm{N}$ and dry weight biomass, respectively, were allocated to the fruit. Although independent of the quantity of $\mathrm{N}$ available from fertilizer and/or soil, harvest index and harvest $\mathrm{N}$ index varied from year to year and ranged from $26.9 \%$ to $38.3 \%$ and $22.4 \%$ to $31.4 \%$, respectively. For both indices, 2004 was significantly higher than 2005 and 2006, which were different from each other. This suggests that for these experimental conditions, biomass and $\mathrm{N}$ partitioning is a characteristic of crop and year rather than $\mathrm{N}$ fertilization.

There was no correlation between $\mathrm{N}$ applied ( 0 to $220 \mathrm{~kg} \mathrm{~N} / \mathrm{ha}$ ) and $\mathrm{N}$ content in the cucumber crop expressed as $\mathrm{Yn}, \mathrm{Vn}$, or $\mathrm{Pn}$ (data not shown). There was, however, a significant positive linear correlation $(P<$ 0.001 ) between $\mathrm{N}$ applied and percent $\mathrm{N}$ content of vegetative and reproductive biomass (Fig. 3). This was consistent with results from several other crops (Everaarts and Booij, 2000; Van Eerd, 2007; Zvomuya and
Rosen, 2002), including cucurbits (Mohammad, 2004), where $\mathrm{N}$ applied correlated with percent $\mathrm{N}$ content and/or $\mathrm{N}$ uptake by the crop. In contrast, Hanna and Adams (1991) showed no correlation between percent $\mathrm{N}$ content and increasing $\mathrm{N}$ rates in cucumber leaves collected before harvest.

Year and $\mathrm{N}$ treatment had a significant effect on percent $\mathrm{N}$ content in the fruit and vegetative biomass, but there was no interaction; therefore, data were pooled over years (Fig. 3). Vegetative and fruit percent $\mathrm{N}$ content displayed a $2005<2004=2006$ and $2004=2005<2006$ trend, respectively. Thus, percent $\mathrm{N}$ content in the cucumber crop appears to be higher in average growing conditions (2006) compared with a hot and dry year (2005) and intermediary in a cool, wet year (2004). However, when converted to $\mathrm{kg} \mathrm{N} /$ ha based on cucumber yield or plant dry weight, there was no difference in $\mathrm{N}$ content in fruit, vegetative biomass, or total plant biomass, likely as a result of variability in weight data. In contrast, $\mathrm{N}$ content in squash vegetative and reproductive tissues was significantly higher in fertilized versus nonfertilized treatments (Mohammad, 2004). The observed differences between cucumbers and squash may be the result of differences in 


\begin{tabular}{|c|c|c|c|c|c|c|c|}
\hline \multirow[b]{3}{*}{ Symbol } & \multirow[b]{3}{*}{$\mathrm{N}$ balance parameters } & \multirow[b]{3}{*}{ Description/calculation } & \multicolumn{4}{|c|}{$\mathrm{N}$ treatments } & \multirow[b]{3}{*}{$P$ value } \\
\hline & & & 0 & 110 & 220 & $65+45$ & \\
\hline & & & \multicolumn{4}{|c|}{ (kg N/ha) } & \\
\hline & $\mathrm{N}$ inputs & & & & & & \\
\hline Sn@P & Soil $\mathrm{N}$ at planting & $\mathrm{NO}_{3}{ }^{-}-\mathrm{N}+\mathrm{NH}_{4}{ }^{+}-\mathrm{N}$ to $30-\mathrm{cm}$ depth & $79(7.1)$ & $79(7.1)$ & $79(7.1)$ & $79(7.1)$ & \\
\hline$P n_{0}$ & Soil-derived plant N & $=P n$ in $0 \mathrm{~N}$ control & $119(10.9)$ & $119(10.9)$ & $119(10.9)$ & $119(10.9)$ & \\
\hline Nin & Total input & $=S n @ \mathrm{P}+F+V n_{0}+Y n_{0}$ & $194(13.1) \mathrm{a}$ & $305(12.6) \mathrm{b}$ & $407(12.7) \mathrm{c}$ & $308(19.3) b$ & $<0.001$ \\
\hline & $\mathrm{N}$ outputs & & & & & & \\
\hline Sn@H & Soil $\mathrm{N}$ at harvest & $\mathrm{NO}_{3}{ }^{-}-\mathrm{N}+\mathrm{NH}_{4}{ }^{+}-\mathrm{N}$ to $30-\mathrm{cm}$ depth & $62(5.4) \mathrm{a}$ & $143(12.3) \mathrm{b}$ & $222(27.4) \mathrm{c}$ & $114(8.4) b$ & $<0.001$ \\
\hline Nout & $\begin{array}{l}\text { Total output } \\
\mathrm{N} \text { balance }\end{array}$ & $=Y n+V n+S n @ H$ & $180(12.2) \mathrm{a}$ & $291(18.8) b$ & $369(32.0) \mathrm{c}$ & $269(18.4) b$ & $<0.001$ \\
\hline & Apparent N loss & $=$ Nin - Nout & $17(9.6)$ a & $19(14.0) \mathrm{ab}$ & $52(32.4) \mathrm{c}$ & $39(13.9) \mathrm{b}$ & $<0.001$ \\
\hline & Crop balance & $=F-(V n+Y n)$ & $-119(10.9) \mathrm{a}$ & $-36(15.9) b$ & $74(14.4) \mathrm{c}$ & $-48(19.0) b$ & $<0.001$ \\
\hline & Crop removal balance & $=F-Y n$ & $-27(3.4) \mathrm{a}$ & $78(5.1) \mathrm{b}$ & $190(4.1) \mathrm{c}$ & $79(3.3) \mathrm{b}$ & $<0.001$ \\
\hline
\end{tabular}

${ }^{\mathrm{z}}$ Data are means with SE from 6 site-years over 2005 and 2006 with four replications at each site. Treatment means within rows followed by different letters were significantly different $(P \leq 0.05)$ based on Tukey-Kramer means separation.

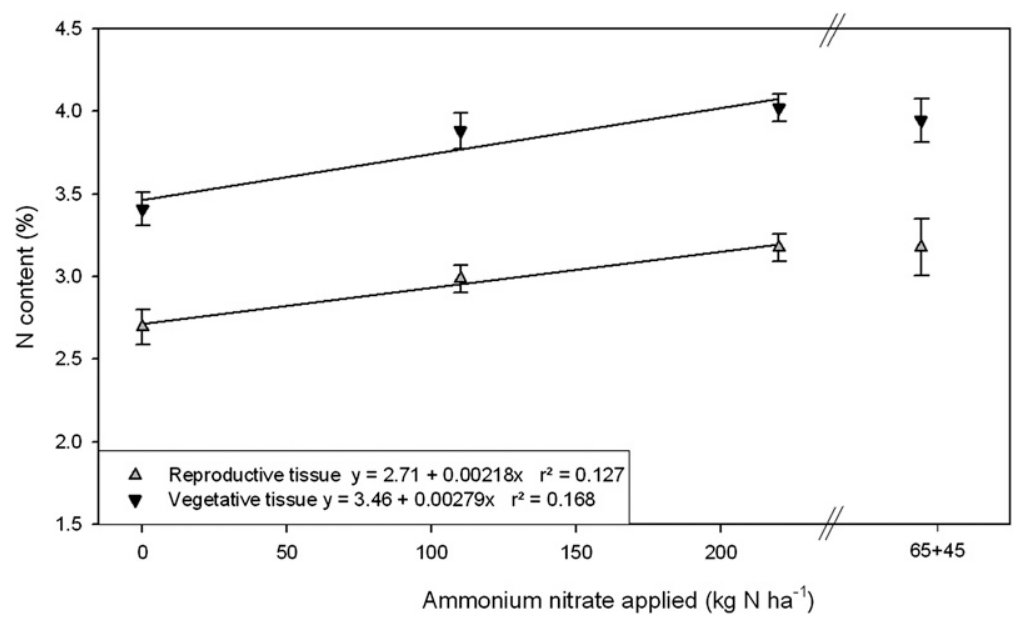

Fig. 3. At harvest, percent nitrogen content in machine-harvested cucumber reproductive (- $\mathbf{\Delta}-)$ and vegetative (- $\mathbf{\nabla}$-) tissues in response to ammonium nitrate broadcast-applied preplant incorporated or split-applied when the vines elongate $(65+45)$. Date averaged across site-years. ${ }^{* * *}$ Correlation coefficients are significant at $P \leq 0.001(\mathrm{n}=95)$.

plant maturity at harvest between these two crops. Machine-harvested cucumbers are harvested while the crop is in the active reproductive stage, but squash is harvested at plant senescence.

As a result of the lack of differences in aboveground plant $\mathrm{N}$ content between $\mathrm{N}$ treatments, differences in $\mathrm{N}$ budget parameters were the result of the quantity of $\mathrm{N}$ applied and, consequently, the quantity of soil mineral $\mathrm{N}$ at harvest (Table 5). Where significant, all $\mathrm{N}$ budget parameters and calculations displayed a $0<110=$ split $<$ $220 \mathrm{~kg} \mathrm{~N} /$ ha trend (Table 5). For example, total N inputs ranged from 254 to $472 \mathrm{~kg} \mathrm{~N} / \mathrm{ha}$ in the 0 and 220 treatment, respectively, which were both significantly different from the 110 and split treatments (Table 5). As expected, increasing applied $\mathrm{N}$ fertilizer from 110 to $220 \mathrm{~kg} \mathrm{~N} /$ ha increased soil mineral N at harvest (Fig. 2) and resulted in higher total $\mathrm{N}$ outputs of 291 versus $369 \mathrm{~kg} \mathrm{~N} / \mathrm{ha}$ and thus more $\mathrm{N}$ available for loss.

The $\mathrm{N}$ balance equations provide an indication of $\mathrm{N}$ potentially available for loss. Apparent N loss (Nin-Nout) was $52 \mathrm{~kg} \mathrm{~N} / \mathrm{ha}$ at the highest rate tested (Table 5). When subtracted from the nonfertilized control, apparent $\mathrm{N}$ loss with $220 \mathrm{~kg} \mathrm{~N} /$ ha applied was $35 \mathrm{~kg} \mathrm{~N} / \mathrm{ha}$, which is a relatively minimal risk of loss. As well, the crop balance $(F-P n)$ indicates that with $110 \mathrm{~kg} \mathrm{~N} /$ ha applied, 36 to $48 \mathrm{~kg} \mathrm{~N} / \mathrm{ha}$, more $\mathrm{N}$ is taken up by the crop than fertilizer $\mathrm{N}$ applied. Regardless, significant quantities of $\mathrm{N}$ remain in the field at cucumber harvest as crop residue $(V n)$ and soil mineral N. Compared with the nonfertilized control, $\approx 87$ to $186 \mathrm{~kg} \mathrm{~N} /$ ha more $\mathrm{N}$ remained in the field when either 110 or 220 $\mathrm{kg} \mathrm{N} / \mathrm{ha}$ had been applied, respectively (Table 5). Moreover, cucumber vegetative tissue mineralizes rapidly and is subsequently available for loss. Another crop or cover crops can be planted after cucumber harvest in July to recover residual $\mathrm{N}$ and potentially minimize $\mathrm{N}$ losses from the agroecosystem (Snapp et al., 2005).

There was at least a $105 \mathrm{~kg} \mathrm{~N} / \mathrm{ha}$ difference in crop removal balance $(F-Y n)$ between treatments. Crop removal balance is a component of the N index within Ontario's nutrient management plan, which sets a crop removal balance of $35 \mathrm{~kg} \mathrm{~N} / \mathrm{ha}$ as a decision point for growers to adopt alternative management practices to mitigate $\mathrm{N}$ loss such as reducing $\mathrm{N}$ rates and/or planting a cover crop. This may be a concern for machine-harvested cucumbers because it is not unusual for southwestern Ontario growers to apply more than $65 \mathrm{~kg} \mathrm{~N} / \mathrm{ha}$, which would likely exceed the decision point of the $\mathrm{N}$ index. There was no effect of year on apparent $\mathrm{N}$ loss and crop removal balance, which may most likely be the result of the short growing season of 6 weeks for machine-harvested cucumber. The observed lack of differences between years simplifies management and regulatory decision-making processes because adjustments do not have to be taken into consideration for year-to-year variations.

Nitrogen use efficiency. Nitrogen treatment had a significant effect on all three NUE indices tested, whereas year significantly affected two of three NUE indices: fertilizer N uptake efficiency and standardized $\mathrm{N}$ removal. There were no significant $\mathrm{N}$ treatment $\times$ year interactions for any NUE indices; therefore, data were pooled across site-years.

Fertilizer $\mathrm{N}$ uptake efficiency and $\mathrm{N}$ uptake efficiency indices reflect increases in plant $\mathrm{N}$ derived from fertilizer $\mathrm{N}$ or fertilizer $\mathrm{N}$ plus soil mineral N, respectively (Table 6). For these indices, in machine-harvested cucumbers, NUE decreased with increasing $\mathrm{N}$ fertilization, but timing of $\mathrm{N}$ had no effect (Table 6). This suggests that the preplant application of $220 \mathrm{~kg} \mathrm{~N} /$ ha was not as efficient as $110 \mathrm{~kg} \mathrm{~N} / \mathrm{ha}$ applied preplant or split. This result was consistent with other studies in which higher $\mathrm{N}$ rates consistently produced lower fertilizer use efficiencies than low and medium rates (Habtegebrial et al., 2007; Nissen and Wander, 2003; Van Eerd, 2007).

Standardized N removal (i.e., the amount of $\mathrm{N}$ removed per tonne of crop) is currently used in nutrient management planning in Ontario to estimate crop removal balance $(F-Y n)$. There was no difference in standardized $\mathrm{N}$ removal between treatments that received $\mathrm{N}$ fertilizer, which were higher than the zero $\mathrm{N}$ control at 1.8 versus $1.5 \mathrm{~kg}$ $\mathrm{N} / \mathrm{t}$, respectively (Table 6). Standardized N 
Table 6. Nitrogen use efficiency indices of machine-harvested cucumbers. ${ }^{\mathrm{z}}$

\begin{tabular}{lccc}
\hline & \multicolumn{3}{c}{ N use efficiency indices ${ }^{\mathrm{y}}$} \\
\cline { 2 - 4 } $\begin{array}{l}\text { N treatment } \\
(\mathrm{kg} \mathrm{N} / \mathrm{ha})^{\mathrm{x}}\end{array}$ & Fertilizer N uptake efficiency & $\mathrm{N}$ uptake efficiency & Standardized N removal \\
\cline { 2 - 4 } & $=\left[\left(P n_{f}-P n_{0}\right) / F n\right] \times 100$ & $=(P n / S n) \times 100$ & $=(Y n / Y w) \times 100$ \\
110 & $27(7.5) \mathrm{a}$ & $178(20.2) \mathrm{a}$ & $1.5(0.08) \mathrm{a}$ \\
220 & $10(4.1) \mathrm{b}$ & $76(7.8) \mathrm{b}$ & $1.7(0.9) \mathrm{b}$ \\
$65+45$ & $36(9.3) \mathrm{a}$ & $48(4.6) \mathrm{c}$ & $1.8(0.10) \mathrm{b}$ \\
$P$ value & 0.056 & $80(8.9) \mathrm{b}$ & 0.004 \\
\hline
\end{tabular}

${ }^{z}$ Data are means with SE from 6 site-years over 2005 and 2006 with four replications at each site.

${ }^{\mathrm{y}}$ Formula symbols are as follows: plant $(P)$, yield $(Y)$, soil $(S)$, weight $(w)$, nitrogen content $(n)$, fertilizer $\mathrm{N}$ treatment $(f)$, and nonfertilized control $(o)$. Units were $\mathrm{kg} \mathrm{N} /$ ha for $\mathrm{N}$ content in fertilizer and soil. For $\mathrm{N}$ use efficiency analysis, soil nitrogen ( $\mathrm{Sn}$ ) consisted of mineral $\mathrm{N}$ content $\left(\mathrm{NO}_{3}{ }^{-}-\mathrm{N}\right.$ and $\left.\mathrm{NH}_{4}{ }^{+}-\mathrm{N}\right)$ at harvest to $30 \mathrm{~cm}$.

${ }^{\mathrm{x}} \mathrm{N}$ treatments were in $\mathrm{kg} \mathrm{N} / \mathrm{ha}$ of ammonium nitrate broadcast-applied preplant incorporated or splitapplied when the vines elongate $(65+45)$. Different letters for each index indicate a statistically significant difference $(P \leq 0.05)$ based on Tukey-Kramer means separation.

removal did differ significantly between years with means of $1.3,1.9$, and $1.6 \mathrm{~kg} \mathrm{~N} / \mathrm{t}$ in 2004 , 2005, and 2006, respectively. Different weather conditions, soils, and disease pressure likely contributed to this variation. Therefore, growers with a nutrient management plan who do not know their crop removal for a particular year are recommended to use a relatively conservative value of $1.7 \mathrm{~kg} \mathrm{~N} / \mathrm{t}$.

There was no difference in all NUE indices between the preplant and split application treatment at $110 \mathrm{~kg} \mathrm{~N} /$ ha (Table 6). Thus, for a machine-harvested cucumber, there appears to be no advantage to splitapplying $110 \mathrm{~kg} \mathrm{~N} / \mathrm{ha}$ in terms of yield (Fig. 1), soil mineral $\mathrm{N}$ at harvest (data not shown), $\mathrm{N}$ budget (Table 5), or NUE (Table 6). Similarly, split N applications also did not improve NUE over the traditional preplant application in spring wheat (Triticum aestivum L.) (Ma et al., 2006) nor did split $\mathrm{N}$ applications increase yields and $\mathrm{N}$ uptake in corn (Torbert et al., 2001) and potato (Solanum tuberosum L.) (Riley, 2001). The primary goal of split-applying $\mathrm{N}$ fertilizer is to minimize $\mathrm{N}$ losses. The short growing season of machine-harvested cucumbers limits the risk of extreme rainfall events that lead to $\mathrm{N}$ losses through leaching and/or denitrification. Moreover, the cucumber season in Ontario is from the end of May to midAugust when typically soils are not saturated as a result of evapotranspiration losses exceeding rainfall. Thus, the likelihood of $\mathrm{N}$ losses is minimal during the cucumber season and the potential benefits of split application minimal. A possible environmental and economic benefit of split applications is that the first application rate is often low and the grower could decide midseason not to apply or to lower the second application, thereby reducing the total fertilizer application to the crop. Nonetheless, it is not known if there would be a benefit of split $\mathrm{N}$ application on cucumber yield, $\mathrm{N}$ dynamics, and/or NUE if the trials were selectively conducted on known N-responsive soils rather than soils typical of cucumber production.

In conclusion, marketable cucumber yield or income response to $\mathrm{N}$ application was either nonresponsive or had a slight positive or negative linear response, which suggests that lower $\mathrm{N}$ rates would have a lower environmental risk and be more economical as a result of lower input costs. Grade size distribution, including culls, and fruit brine quality were not influenced by $\mathrm{N}$ treatment. Based on the zero $\mathrm{N}$ control treatments, the lack of yield response to fertilizer $\mathrm{N}$ was the result of sufficient soil mineral $\mathrm{N}$ over the growing season. The Ontario-recommended rate of $110 \mathrm{~kg} \mathrm{~N} / \mathrm{ha}$ applied split as well as preplant had improved NUE and lower soil mineral $\mathrm{N}$ levels at harvest compared with the $220 \mathrm{~kg} \mathrm{~N} / \mathrm{ha}$. This indicates that an application rate of $220 \mathrm{~kg} \mathrm{~N} / \mathrm{ha}$ is both environmentally and economically undesirable as a result of high soil mineral $\mathrm{N}$ levels at harvest, high apparent $\mathrm{N}$ loss, and unnecessarily higher input costs. However, $110 \mathrm{~kg} \mathrm{~N} / \mathrm{ha}$ is not recommended because there was minimal yield response observed in the fields tested, thus suggesting $110 \mathrm{~kg} \mathrm{~N} / \mathrm{ha}$ may have unnecessarily high environmental and economical risks. For machine-harvested cucumbers grown in southwestern Ontario, 0 or 30 $\mathrm{kg} \mathrm{N} /$ ha seems more appropriate considering the short growing season, timing of planting into warm soils, and the generally productive, nonresponsive soils in the region.

\section{Literature Cited}

Beegle, D.B., O.T. Carton, and J.S. Bailey. 2000 Nutrient management planning: Justification, theory, practice. J. Environ. Qual. 29:72-79.

Doss, B.D., C.E. Evans, and J.L. Turner. 1977. Irrigation and applied nitrogen effects on snap beans and pickling cucumbers. J. Amer. Soc. Hort. Sci. 102:654-657.

Esmel, C.E., B.M. Santos, and A.R. Gilreath. 2006 Effects of nitrogen rates on summer squash growth and yield. HortScience 41:506. (abstr.).

Everaarts, A.P. and R. Booij. 2000. The effect of nitrogen application on nitrogen utilization by white cabbage (Brassica oleracea var. capitata) and on nitrogen in the soil at harvest. J. Hort. Sci. Biotechnol. 75:705-712.

Fang, Q.X., Q. Yu, E.L. Wang, Y.H. Chen, G.L. Zhang, J. Wang, and L.H. Li. 2006. Soil nitrate accumulation, leaching and crop nitrogen use as influenced by fertilization and irrigation in an intensive wheat-maize double cropping system in the North China Plain. Plant Soil 284:335-350.
Ferrante, A., A. Spinardi, T. Maggiore, A. Testoni, and P.M. Gallina. 2008. Effect of nitrogen fertilisation levels on melon fruit quality at the harvest time and during storage. J. Sci. Food Agr. 88:707-713.

Gagnon, B., R.R. Simard, M. Goulet, R. Robitaille, and R. Rioux. 1998. Soil nitrogen and moisture as influenced by composts and inorganic fertilizer rate. Can. J. Soil Sci. 78:207-215.

Goreta, S., S. Perica, G. Dumicic, L. Bucan, and K. Zanic. 2005. Growth and yield of watermelon on polyethylene mulch with different spacings and nitrogen rates. HortScience 40:366-369.

Gregorich, E.G. and M.R. Carter. 2008. Soil sampling and methods of analysis. CRC, Boca Raton, FL.

Habtegebrial, K., B.R. Sing, and M. Haile. 2007. Impact of tillage and nitrogen fertilization on yield, nitrogen use efficiency of tef [Eragrostis tef (Zucc.) Trotter] and soil properties. Soil Till. Res. 94:55-63.

Hanna, H.Y. and A.J. Adams. 1991. Yield increase of staked cucumber by supplemental drip irrigation, reducing plant spacing and higher $\mathrm{N}-\mathrm{P}-\mathrm{K}$ rates. Proc. Fl. State Hort. Soc. 104: 240-244.

Johnson, W.A., C.E. Evans, E.L. Mayton, and W.A. Griffey. 1973. Soil fertility studies with pickling cucumbers in the Piedmont area of Alabama. Ala. Agr. Expt. Sta. Cir. 211.

Locascio, S.J., W.J. Wiltbank, D.D. Gull, and D.N Maynard. 1984. Fruit and vegetable quality as affected by nitrogen nutrition, p. 617-626. In: Hauck, R.D. (ed.). Nitrogen in crop production. Amer. Soc. Agron., Madison, WI.

Ma, B., K. Subedi, and L. Dwyer. 2006. Timing and method of ${ }^{15}$ nitrogen-labeled fertilizer application on grain protein and nitrogen use efficiency of spring wheat. J. Plant Nutr. 29: 469-483.

Mailvaganam, S. 2008. Area, production and farm value of specified commercial vegetable crops, Ontario, 2007. 16 May 2008. <http://www. omafra.gov.on.ca/english/stats/hort/veg_m07. htm>.

Maynard, D.G., Y.P. Kalra, and J.A. Crumbaugh 2008. Nitrate and exchangeable ammonium nitrogen, p. 71-80. In: Gregorich, E.G. and M.R. Carter (eds.). Soil sampling and methods of analysis, CRC, Boca Raton, FL.

McGill, W.B. and C.T. Figueiredo. 2008. Total nitrogen, p. 239-250. In: Gregorich, E.G. and M.R. Carter (eds.). Soil sampling and methods of analysis, CRC, Boca Raton, FL.

Mohammad, M.J. 2004. Squash yield, nutrient content and soil fertility parameters in response to methods of fertilizer application and rates of nitrogen fertigation. Nutr. Cycl. Agroecosyst. 68:99-108

Nissen, T.M. and M.M. Wander. 2003. Management and soil-quality effects on fertilizer-use efficiency and leaching. Soil Sci. Soc. Amer. J. 67:1524-1532.

Olsen, J.K., P.J. Lyons, and M.M. Kelly. 1993. Nitrogen uptake and utilization by bell pepper in subtropical Australia. J. Plant Nutr. 16:177193.

Reiners, S. and D.I.M. Riggs. 1997. Plant spacing and variety affect pumpkin yield and fruit size, but supplemental nitrogen does not. HortScience 32:1037-1039.

Riley, H. 2001. Level and timing of nitrogen fertilizer application to early and semi-early potatoes (Solanum tuberosum L.) grown with irrigation on light soils in Norway. Acta Agr. Scand., Sect. B. Soil \& Plant Sci. 50:122-134. Schultheis, J.R. and R.J. Dufault. 1994. Watermelon seedling growth, fruit yield, and quality 
following pretransplant nutritional conditioning. HortScience 29:1264-1268.

Schultheis, J.R., T.C. Wehner, and S.A. Walters. 1998. Optimum planting density and harvest stage for little-leaf and normal-leaf cucumbers for once-over harvest. Can. J. Plant Sci. 78: 333-340.

Snapp, S.S., S.M. Swinton, R. Labarta, D. Mutch, J.R. Black, R. Leep, J. Nyiraneza, and K. O’Neil. 2005. Evaluating cover crops for ben- efits, costs and performance within cropping system niches. Agron. J. 97:322-332.

Torbert, H.A., K.N. Potter, and J.E. Morrison. 2001. Tillage system, fertilizer nitrogen rate, and timing effect on corn yields in the Texas Blackland Prairie. Agron. J. 93:1119-1124.

Umamaheswarappa, P. and K.S. Krishnappa. 2004. Effect of nitrogen, phosphorus and potassium on cucumber cv. Poinsette grown in dry region of Southern India. Trop. Sci. 44:174-176.
Van Eerd, L.L. 2007. Evaluation of different nitrogen use efficiency indices using fieldgrown green bell peppers (Capsicum anпиит L.). Can. J. Plant Sci. 87:565-569.

Zvomuya, F. and C.J. Rosen. 2002. Biomass partitioning and nitrogen use efficiency of 'Superior' potato following genetic transformation for resistant to Colorado potato beetle. J. Amer. Soc. Hort. Sci. 127:703709. 